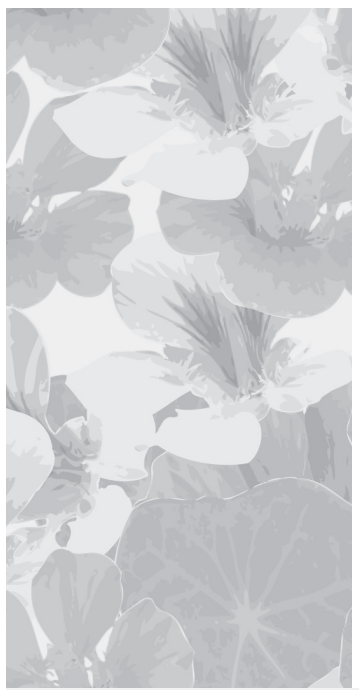

\title{
A new in vitro protocol for assessing phototoxic effects of xenobiotics on human keratinocytes
}

\section{Nowy protokół oceny in vitro fototoksycznego działania ksenobiotyków na ludzkie keratynocyty}

\author{
Radoslaw Spiewak ${ }^{1,2}$, Aleksandra Gregorius ${ }^{1}$, Piotr Sznelewski ${ }^{3}$
}

${ }^{1}$ Jagiellonian University Medical College, Department of Experimental Dermatology and Cosmetology, Krakow, Poland

${ }^{2}$ Institute of Dermatology, Celimun Laboratory, Krakow, Poland

Military Medical Institute, Doctoral Studies, Warsaw, Poland

Estetol Med Kosmetol 2012; 2(4): 110-114

DOI: http://dx.doi.org/10.14320/EMK.2012.023

\begin{abstract}
Routine protocols of phototoxicity tests are based on cultured mouse fibroblasts, mainly because these cells are robust and easy to culture in vitro. However, in a real-life situation, phototoxic reactions take place primarily in the epidermis, comprised of keratinocytes - cells which differ substantially from fibroblasts with regard to structure and function. Therefore, keratinocyte cultures seem more appropriate for the phototoxicity testing of xenobiotics, such as cosmetic ingredients or drugs. Aim: To design and implement a test protocol for in vitro assessment of phototoxic properties of xenobiotics in normal human keratinocytes. Material and methods: As a starting point, we applied the EU-approved protocol for testing phototoxicity in mouse fibroblast cultures (3T3 Neutral Red Uptake Phototoxicity Assay, DB-ALM No. 78). The protocol was modified and adjusted in a series of experiments to the specific demands of cultured normal human keratinocytes. After obtaining a stable growth of keratinocytes in microcultures, the cells were exposed for 1 hour to model agents with phototoxic properties known from clinical observations: chlorpromazine, 8-methoxypsoralen, chloroquine, promethazine, etofenamate, ketoprofen, doxycycline, lymecycline, and isotretinoin in a series of concentrations of $0,1,3,11,33$, and $100 \mathrm{~g} / \mathrm{ml}$. Subsequently, the cultures were exposed to the cumulative dose of $5 \mathrm{~J} / \mathrm{cm}^{2}$ of artificial sunlight using the EU-recommended solar simulator. The survival of keratinocytes was assessed by their uptake of neutral red (NR) dye. Results: Using the proposed test protocol, we were able to achieve stable growth of normal adult human keratinocytes in vitro. In the absence of phototoxic agents no effects of light on cell viability were noticeable up to the dose of $10 \mathrm{~J} / \mathrm{cm}^{2}$. The proposed system was capable of demonstrating phototoxicity of model phototoxic xenobiotics selected for the tests, which was in line with the clinical experience regarding phototoxic effects of these agents in humans. Conclusions: We have developed an in vitro protocol for assessment of the phototoxic potential of xenobiotics in normal human keratinocytes. Its functionality and reliability has been confirmed by tests results with known phototoxic agents. Although more difficult to culture than mouse fibroblasts, and therefore neglected in routine phototoxicity testing, human keratinocytes seem more appropriate for predicting in vitro phototoxic effects of xenobiotics in human skin, as phototoxic processes predominantly involve the epidermis which consists of keratinocytes.
\end{abstract}

Keywords: phototoxicity testing, xenobiotics, in vitro tests, keratinocyte cultures, human keratinocytes

\section{Streszczenie}

Protokoły stosowanych rutynowo testów fototoksyczności wykorzystują hodowle mysich fibroblastów ponieważ komórki te są mało wymagające i łatwo dają się hodować in vitro. Jednak w rzeczywistości reakcje fototoksyczne w głównej mierze obejmują naskórek, który zbudowany jest z keratynocytów - komórek znacznie różniących się od fibroblastów pod względem struktury i funkcji. Dlatego hodowle keratynocytów wydają się bardziej adekwatne dla testowania fototoksyczności ksenobiotyków takich, jak składniki kosmetyków czy leki. Celem przedstawionych badań było opracowanie i wdrożenie protokołu testu oceniającego potencjał fototoksyczny ksenobiotyków w hodowlach normalnych ludzkich keratynocytów. Materiat i metody: Za punkt wyjścia dla naszych poszukiwań posłużył nam zaakceptowany przez EU protokót badania fototoksyczności na fibroblastach mysich (3T3 Neutral Red Uptake Phototoxicity Assay, DB-ALM No. 78). Na podstawie szeregu eksperymentów protokót ten został zmodyfikowany i dostosowany do szczególnych wymagań hodowli normalnych ludzkich keratynocytów. Po uzyskaniu stabilnego wzrostu keratynocytów w hodowlach, zostały one przez 1 godzinę poddane dziataniu modelowych substancji o dziataniu fototoksycznym znanych z obserwacji klinicznych: chlorpromazyny 8-metoksypsoralenu, chlorochiny, prometazyny, etofenamatu, ketoprofenu, doksycykliny, limecykliny oraz izotretinoiny w serii stężeń $0,1,3,11,33$ i $100 \mu \mathrm{g} / \mathrm{ml}$. Następnie mikrohodowle zostały naświetlone sztucznym światłem stonecznym z rekomendowanego przez EU symulatora stonecznego w całkowitej dawce $5 \mathrm{~J} / \mathrm{cm}^{2}$. Żywotność keratynocytów była oceniana na podstawie wychwytywania przez komórki barwnika czerwieni neutralnej (NR). Wyniki: Stosując wypracowany protokół badania byliśmy w stanie uzyskać stabilny wzrost normalnych ludzkich keratynocytów in vitro. Przy nieobecności czynników fototoksycznych, światło w dawce do $10 \mathrm{~J} / \mathrm{cm}^{2}$ nie wpływało zauważalnie na żywotność keratynocytów. Zaproponowany model wyraźnie ujawniał fototoksyczność modelowych czynników fototoksycznych wybranych do niniejszych badań, zgodnie z obserwacjami klinicznymi u ludzi. Wnioski: Opracowaliśmy protokół badania in vitro potencjału fototoksycznego ksenobiotyków w normalnych ludzkich keratynocytach. Funkcjonalność i wiarygodność testu została potwierdzona w eksperymentach z wykorzystaniem ksenobiotyków o znanym działaniu fototoksycznym. Mimo, że w hodowli bardziej wymagające od mysich fibroblastów i w związku z tym pomijane w rutynowych badaniach fototoksyczności, ludzkie keratynocyty wydają się bardziej adekwatne w ocenie in vitro potencjalnego działania fototoksycznego ksenobiotyków na ludzką skórę, ponieważ reakcje fototoksyczne w pierwszym rzędzie obejmują naskórek, który składa się z keratynocytów.

Stowa kluczowe: badanie fototoksyczności, ksenobiotyki, testy in vitro, hodowle keratynocytów, keratynocyty ludzkie

Copyright @ 2012 the Authors (text) and Radosław Śpiewak (layout \& journal compilation). All rights reserved. 
The terms "phototoxic reaction" and "phototoxicity" refer to inflammatory reactions of the skin that result from direct cellular damage caused by the interaction of photoactive xenobiotics (photosensitizers) and light. The activation spectrum of such chemicals expands from visible light through UVA to UVB [1]; however, the causative wavelength is within the UVA range in most cases [2]. Resulting skin inflammation is reaction to unspecific damage caused either by free radicals (nonphotodynamic reactions) or reactive oxygen or nitrogen species (photodynamic reactions) [3]. The most common clinical manifestation of phototoxicity is an exaggerated sunburn-like response in exposed areas. In contrast to "classical" sunburn, however, skin inflammation is provoked by low UV doses that are otherwise well tolerated [2]. No individual- or photosensitizer-specific predisposition is a prerequisite for phototoxic reaction, which means that phototoxicity may occur already on the first encounter in every exposed person [3]. This feature of phototoxic reactions indicates the need for testing all compounds coming into contact with human skin for their phototoxic potential.

The present EU-recommended protocol for in vitro phototoxicity testing [4] is based on mouse fibroblast cultures, mainly because these cells are easy to maintain in cultures. However, in a real-life situation, in the first instance, phototoxic reactions involve the most external layer of the body - the epidermis, which is composed of keratinocytes (KC). Moreover, a wide array of xenobiotics (e.g., cosmetic ingredients, topical drugs) are applied directly on the skin surface and may be prone to binding to and accumulating in the epidermis. Therefore, human keratinocyte cultures seem more appropriate for predicting phototoxic properties of xenobiotics, as well as for studies aimed at a better understanding of the mechanisms of phototoxicity.

\section{Aim}

The study was aimed at designing and implementing an in vitro protocol for assessment of the phototoxic properties of xenobiotics in normal human keratinocytes.

\section{Material and methods}

As the starting point for our research, we adopted the 3T3 Neutral Red Uptake (NRU) Phototoxicity Assay protocol for testing phototoxicity in mouse fibroblast cultures [4]. In a series of experiments, the protocol was modified and adjusted to meet the specific demands of keratinocyte $(\mathrm{KC})$ cultures. We applied commercially-available, normal adult human KC (Clonetics Normal Human Epidermal Keratinocytes - NHEK, Lonza). After thawing the cryopreserved cells, they were suspended in keratinocyte growth medium (KGM-Gold BulletKit, Lonza) supplemented with gentamicin, amphotericin
B, epinephrine, hydrocortisone, transferrin, insulin, recombined human epidermal growth factor (rhEGF) and bovine pituitary extract (BPE). The cells were then divided into aliquots of 50,000-100,000 KC per one cell culture flask (bottom area $25 \mathrm{~cm}^{2}$ ), each flask filled with $5 \mathrm{ml} \mathrm{KGM}$, and incubated at $37^{\circ} \mathrm{C}, 95 \%$ relative humidity $(\mathrm{RH})$, and $5 \% \mathrm{CO}_{2}$. The medium was refreshed 3 times a week, each time the cells were controlled visually in an inverted microscope for their condition and possible contaminations. When the flask bottom was covered by $\mathrm{KC}$ in $70-80 \%$, the cells were trypsinized and divided into new culture flasks, approximately $100,000 \mathrm{KC}$ each. After expanding the KC to numbers sufficient for the subsequent tests, the cells were harvested by trypsinization, brought into suspension at the density of $100,000 \mathrm{KC}$ per $1 \mathrm{ml}$ of KGM, which was aliquoted at $0.1 \mathrm{ml}(10,000 \mathrm{KC})$ per well in 96-well, flat-bottom sterile polystyrene culture clusters, and left overnight in the incubator to settle down. The next day, the microcultures were checked for viability and density (fig. 1). Subsequently, the culture medium in the microwells was replaced, each one with $100 \mu 1$ solutions of model phototoxic agents at 5 concentrations $(0,1,3,11$, 33, and $100 \mu \mathrm{g} / 1 \mathrm{ml}$ ) in Earle's Balanced Salt Solution (EBSS).

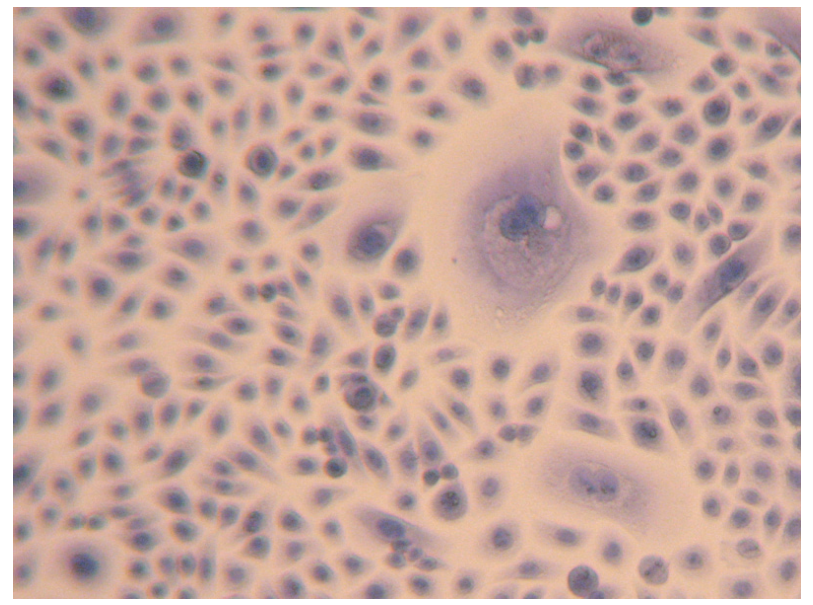

Figure 1. Human keratinocyte microculture in a 96-well flat-bottom culture cluster. Full coverage of the bottom by the cells and numerous mitotic figures are seen throughout the sight field which indicates that the microcultures are good for the NRU assay. For the purpose of photography, the cultures were fixed with ethanol and stained with trypan blue. In routine use, non-stained live cells are observed in an inverted microscope, magnification $\times 100$

As this was a proof-of-concept study, we tested in our model xenobiotics with well-documented phototoxic properties: chlorpromazine (CPZ), 8-methoxypsoralen (8-M), chloroquine (CQ), promethazine (PMZ), etofenamate (ETO), ketoprofen (KET), doxycycline (DOX), lymecycline (LYM), and isotretinoin (ISO) along with dimethyl sulfoxide (DMSO) which was used as the solvent for isotretinoin. The concentration range for tested xenobiotics was selected following suggestions by 
Neumann et al. [5]. A second set of identical microcultures was prepared in parallel to serve as the non-irradiated control. After $1 \mathrm{~h}$ incubation with tested agents, one set of microcultures was exposed to artificial sunlight from the EU-recommended solar simulator (SOL-500 lamp with H1 filter, Hönle) which covers the whole spectrum of sunlight [6]. The cultures were exposed to the light at intensity $1.5 \mathrm{~mW} / \mathrm{cm}^{2}$ up to the cumulative dose of $5 \mathrm{~J} / \mathrm{cm}^{2}$ (duration of irradiation $55.5 \mathrm{~min}$ ). The intensity of irradiation and the cumulative dose was monitored with a dosimeter (Variocontrol, Waldmann) placed next to the irradiated culture clusters. The second set of microcultures (controls) were wrapped in aluminum foil to prevent irradiation, and kept in the solar simulator next to their irradiated counterparts in order to ensure identical ambient conditions for all compared cultures (fig. 2).

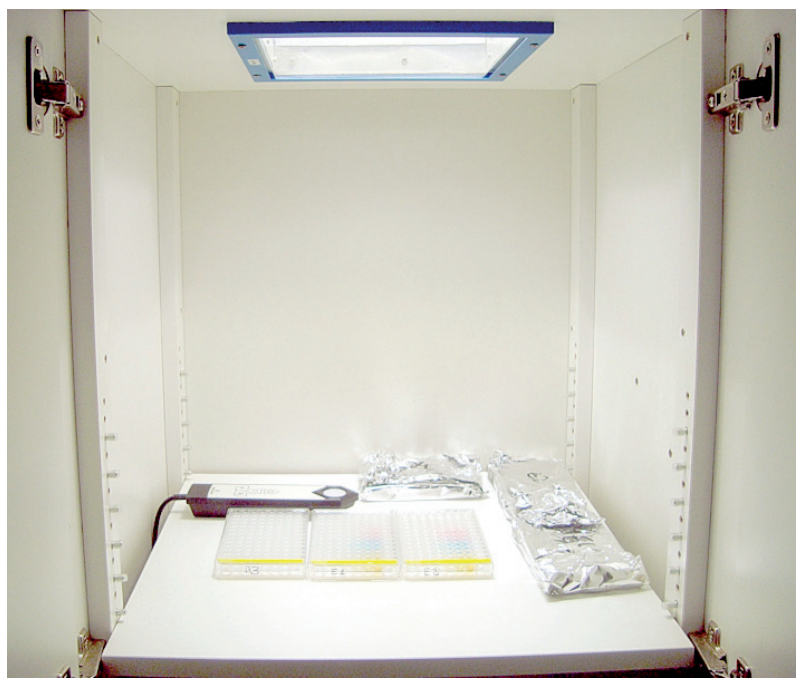

Figure 2. Exposure of human keratinocyte cultures in a solar simulator. Artificial sunlight is passed through the filter glass window in the chamber's ceiling. A dosimeter head placed next to the irradiated clusters is for the purpose of monitoring the momentary energy density and counting cumulative irradiation dose in real time. Identical control cultures were wrapped in aluminum foil in order to ensure identical ambient conditions. The chamber temperature was controlled by a thermostatic fan (not visible in the photograph)

After irradiation, all wells in the culture clusters were emptied, rinsed with fresh EBSS, filled with fresh $\mathrm{KGM}$ medium, and incubated overnight at $37^{\circ} \mathrm{C}, 95 \%$ $\mathrm{RH}$, and $5 \% \mathrm{CO}_{2}$. On the last day of the experiment, the viability of $\mathrm{KC}$ was measured with the use of the long-established neutral red (NR) uptake assay, which is based on the phenomenon of active uptake of NR by live cells; thus, the accumulation of the dye within keratinocytes was used as a measure of cell viability [7]. The cultures were incubated with KGM medium supplemented with $50 \mu \mathrm{g} / \mathrm{ml} \mathrm{NR}$ for $3 \mathrm{~h}$ at $37^{\circ} \mathrm{C}, 95 \%$ $\mathrm{RH}, 5 \% \mathrm{CO}_{2}$. Subsequently, the culture clusters were emptied and centrifuged bottom-up at $300 \times \mathrm{g}$ for $3 \mathrm{~min}$ in order to remove from wells all remaining fluid with non-absorbed NR. Following this, each culture was treated with $150 \mu \mathrm{l}$ colour desorb solution (1\% glacial acetic acid, 50\% ethanol, 49\% water), and left for $10 \mathrm{~min}$ on a plate shaker to ensure complete extraction of the NR from within the cells. Immediately after that, the absorbance was measured in the wells using a microplate reader ELx808 (BioTek) fitted with a $515 \mathrm{~nm}$ filter. To reduce random variability, each microculture was tested in triplicate and arithmetic means of all 3 results were taken for further analyses.

\section{Results}

The culture clusters after desorption of NR from keratinocytes are shown in figure 3. The strongest phototoxicity to normal human keratinocytes was caused by chlorpromazine (CPZ) with less than 5\% KC staying alive already at the $\mathrm{CPZ}$ concentration of $3 \mu \mathrm{g} / \mathrm{ml}$ (fig. 4). $\mathrm{CPZ}$ also demonstrated some toxicity on $\mathrm{KC}$ in the absence of light; however, more than $50 \% \mathrm{KC}$ were still live at $33 \mu \mathrm{g} / \mathrm{ml}$ (fig. 5). Similar patterns were observed for promethazine (PMZ). 8-methoxypsoralen (8-M) caused a clear decrease in the viability of $\mathrm{KC}$ of more than $50 \%$ already at $1 \mu \mathrm{g} / \mathrm{ml}$; however, further increase of the agent's concentration did not seem to cause a further decrease in $\mathrm{KC}$ viability. In our system, chloroquine (CQ) demonstrated only slight toxicity to $\mathrm{KC}$; moreover, this effect seemed independent of irradiation (compare figs. 4 and 5). From the two non-steroidal anti-inflammatory drugs - ketoprofen (KET) and etofenamate (ETO), both demonstrated a clear dose-dependent phototoxicity, yet only ETO turned out to be toxic for $\mathrm{KC}$ also in the absence of light. Of two tested anti-acne antibiotics, doxycyclin (DOX) turned out to be clearly more phototoxic than lymecycline (LYM), while moderate light-independent toxicity to $\mathrm{KC}$ seemed similar for both drugs. The proposed human keratinocyte model could also demonstrate clear phototoxic properties of isotretinoin (ISO). As ISO is water insoluble, dimethyl sulfoxide (DMSO) was used as a solvent in this case. DMSO alone caused neither any detectable toxicity nor phototoxicity in keratinocyte cultures.

\section{Discussion}

To date, the widely-adopted phototoxicity protocols are based on mouse fibroblast cultures, which seems partly justified considering the fact that UVA can penetrate into the dermis; therefore, fibroblasts may also be involved in phototoxic reactions. On the other hand, keratinocytes $(\mathrm{KC})$ that form the epidermis are exposed to light (including UVB) in the first instance. The biological effects of the UVA are also arguably more pronounced in the epidermis which is exposed directly to UVA. Moreover, in the case of external exposure to phototoxic agents (e.g. from cosmetics, external drugs, or plants), their biologically-active doses will be highest in the 


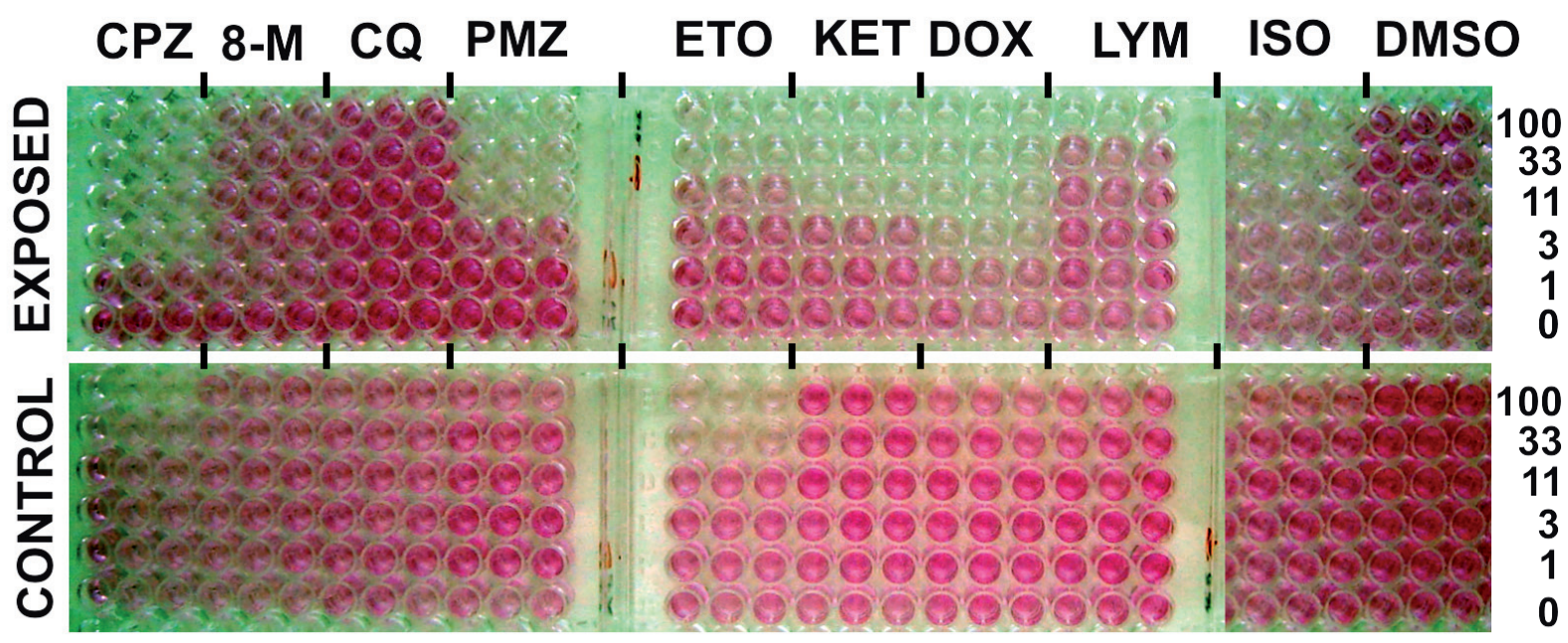

Figure 3. Culture clusters immediately after extracting indicator dye neutral red (NR) from live keratinocytes. The more intense the colour, the more viable cells were present in each well. Values at the right-hand margin indicate concentrations (in $\mu \mathrm{g} / \mathrm{ml}$ ) of tested xenobiotics in each row. Each xenobiotic's concentration was tested in triplicate. CPZ - chlorpromazine, 8-M-8-methoxypsoralen, CQ - chloroquine, PMZ - promethazine, ETO - etofenamate, KET - ketoprofen, DOX-doxycycline, LYM - lymecycline, ISO - isotretinoin, DMSO - dimethyl sulfoxide (diluent for isotretinoin)

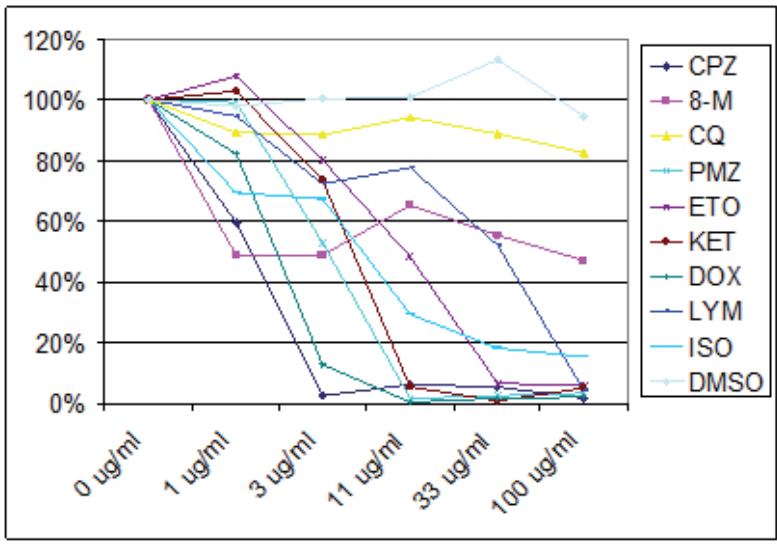

Figure 4. Results for irradiated human keratinocytes, expressed as \% of values read in microcultures not exposed to the tested xenobiotics (irradiated control, $0 \mu \mathrm{g} / \mathrm{ml}$ ). Values on the y-axis represent the amount of accumulated NR dye, considered as a indicator of cell viability. Abbreviations in caption to fig. 3

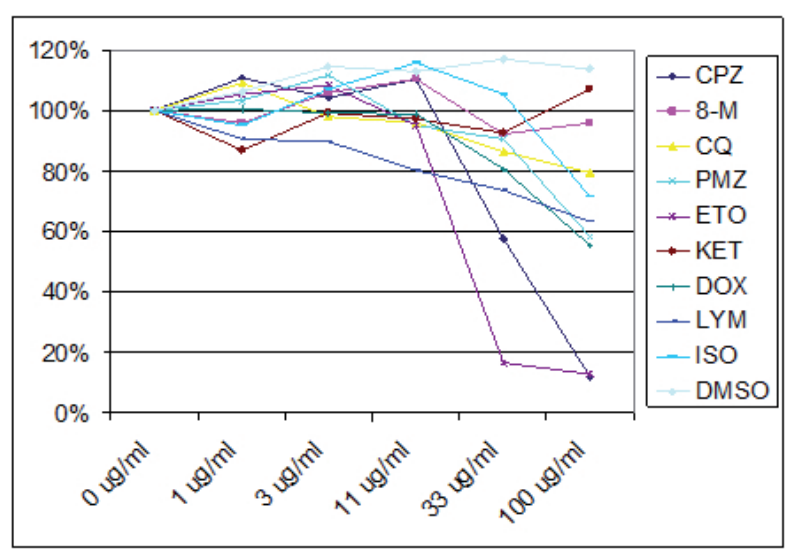

Figure 5. Results for non-irradiated human keratinocytes (controls). For more explanations see caption to fig. 4 epidermis. Therefore, it seems reasonable to implement human keratinocyte-based systems for assessing phototoxic properties of xenobiotics. The fibroblast-based methods implemented nowadays, however robust, raise questions about whether they really reflect the processes that occur in humans in real life situations.

In the proposed human keratinocyte-based system we could clearly reproduce in vitro phototoxic effects of drugs known as phototoxic from clinical observations. There were two surprising exceptions. The first was lack of expected phototoxicity of chloroquine (CQ, compare figs. 4 and 5), although we observed a moderate light-independent toxicity of this agent toward KC. A post-hoc literature search (PubMed, query ,quinidine[title] AND phototox*") retrieved only one clinical report of CQ phototoxicity [8], which might indicate that this drug may be actually less phototoxic in humans than we initially assumed. The second, apparently more relevant discordance from the expected, was the lack of dose-response relationship in the case of 8-methoxypsoralen (8-M): In our case, the $\mathrm{KC}$ viability was reduced by $50 \%$ already at the lowest concentration tested $(1 \mu \mathrm{g} /$ $\mathrm{ml}$ ), and did not decrease any further with increasing 8 -M doses up to $100 \mu \mathrm{g} / \mathrm{ml}$, which was somewhat against expectations as historical experiments in humans showed a clear dose-response [8]. This observation requires further study, although a possible explanation could a technical error, e.g. resulting from reaching the saturation point around the lowest concentration due to wrongly-selected solvent. We have used ethanol in the stock solution and EBSS for further dilutions in a series.

In this proof-of-concept study, we used one range of concentrations for all tested xenobiotics. We believe that future analyses should focus on concentrations that 
can indeed be found in a real-life situation. Test concentration ranges for the xenobiotics of interest should be thus selected based on estimates of concentrations in the epidermis that could result from both normal use, or and thinkable extreme exposure levels (e.g. misuse, accidental exposures). This approach should be adopted for all kinds of xenobiotics - from topical drugs and cosmetic ingredients, to internal drugs, industrial chemicals, and all other environmental xenobiotics with possible phototoxic properties.

\section{Conclusions}

We have presented a working system for the assessment of photoxicity of xenobiotics in cultured, normal human keratinocytes. This study is a starting point for the development of a model for predicting the phototoxicity of xenobiotics within the ranges that correspond with real-life exposures.

\section{References}

1. Gonzalez E, Gonzalez S: Drug photosensitivity, idiopathic photodermatoses, and sunscreens. J Am Acad Dermatol 1996;35(6):871-85.

2. Hölzle E, Lehmann P, Neumann N: Phototoxic and photoallergic reactions. J Dtsch Dermatol Ges 2009;7(7):643-9.

3. Spiewak R: The substantial differences between photoallergic and phototoxic reactions. Ann Agric Environ Med 2012;19(4):888-9.

4. EURL ECVAM: 3 T3 Neutral Red Uptake (NRU) Phototoxicity Assay, DB-ALM No. 78. URL: http:// ihcp.jrc.ec.europa.eu/our labs/eurl-ecvam/validationregulatory-acceptance/doc-phototox/INVITTOXDB-ALM-78.pdf (electronic document, accessed on 1.05.2012).

5. Neumann NJ, Blotz A, Wasinska-Kempka G, Rosenbruch M, Lehmann P, Ahr HJ, Vohr HW: Evaluation of phototoxic and photoallergic potentials of 13 compounds by different in vitro and in vivo methods. J Photochem Photobiol B 2005;79(1):25-34.

6. Moseley H, Ferguson J: Which light source should be used for the investigation of clinical phototoxicity: monochromator or solar simulator? Photodermatol Photoimmunol Photomed 2010;26(1):3-6.
7. Borenfreund E, Babich H, Martin-Alguacil N: Comparisons of two in vitro cytotoxicity assays - The neutral red (NR) and tetrazolium MTT tests. Toxicol In Vitro 1988;2(1):1-6.

8. Selvaag E: Vitiligo caused by chloroquine phototoxicity. J R Army Med Corps. 1998;144(3):163-5.

9. Ljunggren B, Bjellerup M, Carter DM: Dose-response relations in phototoxicity due to 8-methoxypsoralen and UV-A in man. J Invest Dermatol 1981;76(2):73-5.

10. Śpiewak R, Gregorius A, Sznelewski P: Opracowanie protokołu do oceny in vitro efektu fototoksycznego ksenobiotyków na keratynocyty. Przegl Dermatol 2012;99(4):443-4.

\section{Financing and conflict of interest}

The materials used in the presented study were financed from a statutory grant of the Jagiellonian University Medical College (No. K/ZDS/001906), Krakow, Poland. The described experiments were carried out in the Celimun Laboratory of the Institute of Dermatology in Krakow. Preliminary results of the study were presented at the Congress of the Polish Society of Dermatology, 19-22 September 2012 [10]. The authors declare no conflict of interest with regard to the content of this publication.

\section{Address for correspondence}

Radoslaw Spiewak, Professor and Head Department of Experimental Dermatology and Cosmetology Jagiellonian University ul. Medyczna 9, 30-688 Krakow, Poland Tel.: +48 1262058 30, Fax: + 48126205645 E-mail: spiewak.eu@gmail.com

Submitted: 12 August 2012 Accepted: 19 October 2012 